heightened by disturbing feelings of identity. The "apes", skeletons are in our cupboard!

It must be explained that in this book the word "apes" is used in its historical sense and includes all the higher primates. In this way the scope of the book and its historical depth have been increased.

The book has been written from the points of view of the authors' principal disciplines, history and behavioural science; a happy combination of talents which has produced a well illustrated, readable and entertaining book. The earlier chapters treat us to "apes" as sacred objects, buffoons, entertainers, lovers and sex maniacs, while the later chapters are devoted to more serious aspects of the "apes" "early history, social life and behaviour. So much of their social life and behaviour, however, is of a sexual nature that one fears for the authors' contention that this book will tell us about the true character of man. If this is so, we must be deeply grateful that things are no worse than they are!

The section devoted to the "ape" as an animal is a sound, if popular, account of the evolution and spread of modern primate groups. This is followed by a review of the present state of primate behavioural science which goes a long way towards achieving an introductory synopsis for the student as well as the general reader. The complexities of this fast developing subject are presented in a fluent and interesting way to round off a book which will be enjoyed by anyone who has an interest in our nearest living relations.

M. H. DAY

\section{AN INTRODUCTION TO NITROGEN FIXATION}

\section{Nitrogen Fixation in Plants}

By William D. P. Stewart. Pp. $168+7$ plates. (London: The Athlone Press, University of London, 1966. Distributed by Constable and Co., Ltd.) 25s. net.

THE biological fixation of gaseous nitrogen is acknowledged as second only to photosynthesis among the fundamental processes in nature. Equally appreciated have been the difficulties of accurately measuring nitrogen fixation and of preparing cell free systems which would effect fixation. The application of both heavy and light isotopes of nitrogen, however, now permits routine, sensitive determinations of fixation to be made, while the elucidation by several workers in 1960 of conditions conducive to cell free fixation has resulted in considerable understanding of the process at the enzyme level. Within the confines of a brief monograph Dr. Stewart has assembled many relevant data from an extensive and scattered literature. All groups of nitrogen fixers are discussed and their physiology, biochemistry and cytology are described in clear, precise language. The final chapter details the importance of nitrogen fixation in the field and its significance in soil fertility, thereby providing an appropriate conclusion to the subject.

Adverse criticisms of this book are few and of a secondary nature. It is unfortunate that the use of the name diphosphopyridine nucleotide is retained while the recommended co-enzyme nomenclature (NAD) is offered as mere synonymy. The term "phyllosphere" is defined incorrectly and the imperfect fungus Phoma is assigned erroneously to the basidiomycetes. "Nitrogen hydrolysis" is postulated as a possible mechanism for the initial fixation of the gas; this statement is not elaborated and the concept itself is without foundation. A pleasing feature is the inclusion of experimental details, and here the application of newer research techniques such as electron paramagnetic resonance might have been mentioned. Reconstruction of the evolutionary course of nitrogen fixing systems is a speculative exercise and Dr. Stewart does not indulge his readers. It is evident that the pheno- menon is widely occurring in micro-organisms, however, and J. de Ley and I. W. Park (Antonie van Leeuwenhoek, $32,6 ; 1966)$ have recently shown thar nitrogen fixing bacteria are very diverse genetically and suggest that this assimilatory capacity is phylogenetically primitive.

Nitrogen Fixation in Plants is priced and organized admirably for the needs of undergraduates reading botany, microbiology or agriculture, and the balance of the book is such that a comprehensive introduction to the process is presented. The numerous references to the original literature also cater for the postgraduate or specialist reader.

AlaN T. BULI

\section{GEOGRAPHICAL HUMANISM}

\section{Human Nature in Geography}

Fourteen Papers, 1925-1965. By John Kirtland Wright. Pp. $x x+359$. (Cambridge, Mass., and London: Harvard University Press, 1966.) $80 s$. net.

It has become a common practice in recent vears for: distinguished scientists in their years of retirement to collect and republish, with or without editing and emendations, the more important of their contributions to the advancement of knowledge. This has partly taken the place of an autobiography especially when, as in this case, the author has allowed himself to add four essays not previously published to the ten he has selected.

John Kirtland Wright was born on November 30, 1891, and graduated at Harvard in 1913. Giving up an early intention to teach history he joined the staff of the American Geographical Society of New York where he remained for thirty-six years, serving as librarian from 1920, its director from 1937 to 1949 and continuing in research until 1956. In a brief autobiographical introduction he explains how he developed an intense interest in both geography and history about the time of the Spanish. American War and, before he had reached his teens, had written extensively in science fiction including the exploration, geography and history of an entirely imaginary country of "Cravay". Historically inclined, mathematically as well as geographically minded, he became an erudite scholar of international repute, and earned in 1955 the highest award of the Royal Geographical Society, the Patron's Medal, but he never lost the whimsical approach and puckish humour of his boyhood. Indeed, the last essay in this collection, previously unpublished and entitled "Notes on Early American Geopiety" is a delightful return to fantasy, with an underlying sense of neglected values. Quoting from the Psalms he says, "These glorious verses express pious emotion evoked by the wonder and the terror of the earth in all its diversity . . . there being no established term for piety of this sort I have coined one, geopiety (adj. geopious)". There is a similar originality and freshness of approach in all the fourteen essays. The earliest from 1925 is "A Plea for the History of Geography"- - a plea which had a marked international impact in the years which followed. The title chosen for the collection is elaborated in at least four of the essays: "Human Nature in Science" (1944); "Map Makers are Human: Comments on the Subjective in Maps" (1942); "The Place of Imagination in Geography" (1946), and "What's 'American' about American Geography?" (1956 and 1964).

Dr. Wright's interest in the human factor in scientific achievement is illustrated by two penetrating analyses of the work and influence respectively of Daniel Coit Gilman (1831-1908), first President of Johns Hopkins, and Ellen Churchill Semple (1863-1912), whose Influences of Ceographic Environment is eurrently rated as always "one of the groat formative works in the English-speaking world" or an "out-dated and out-moded classic". The modern trend towards quantification is given an historical setting in a new essay, "Notes on Measuring and Counting 